\title{
Statyba
}

\section{A NEW PREDICTOR-MULTICORRECTOR ALGORITHM FOR TIME INTEGRATION IN STRUCTURAL DYNAMICS}

\section{R. Baušys}

To cite this article: R. Baušys (2000) A NEW PREDICTOR-MULTICORRECTOR ALGORITHM FOR TIME INTEGRATION IN STRUCTURAL DYNAMICS, Statyba, 6:5, 345-350, DOI: 10.1080/13921525.2000.10531612

To link to this article: https://doi.org/10.1080/13921525.2000.10531612

曲 Published online: 26 Jul 2012.

Submit your article to this journal $₫$

Џلll Article views: 101 


\section{A NEW PREDICTOR-MULTICORRECTOR ALGORITHM FOR TIME INTEGRATION IN STRUCTURAL DYNAMICS}

\section{R. Baušys}

\section{Vilnius Gediminas Technical University}

\section{Introduction}

In many engineering applications of dynamical design, analysis and control of mechanical and structural systems the need for fast and accurate computational methods is essential. Progress made in developing and understanding direct time integration methods for general computational structural dynamics applications has been well documented in [1-4]. This includes development of efficient computational and mixed time integration methods, investigations encompassing accuracy and stability properties. A wide range of problems, including elastodynamics, adhesive-diffusive systems associated with fluid dynamics has been solved using methods in which the unknown parameters were assumed to be continuous with respect to time. Many traditional ordinary differential equation algorithms were rederived in this manner [5].

Another approach, working from the differential equation viewpoint, has been derived in recent years. The idea is to approximate the unknown fields using time-discontinuous functions [6]. The application of time-discontinuous Galerkin (DG) method leads to A-stable, higher order accurate solution procedures for ordinary differential equations and provides a new possibilities for the development of adaptive strategies. This is in contrast to the conditional stability of some time-continuous Galerkin methods. Much research was conducted by Hulbert [7] to apply time-discontinuous Galerkin methods to computational structural dynamics. A new version of DG approach was presented in [8]. This DG scheme is constructed using weighting exponential function for the inner product. This weighting function is used when the basis functions of temporal domain have degree two or higher. The proposed time finite element strategy enables us to overcome aforementioned disadvantage of Galerkin least squares approach, the case when the least squares terms destroy the banded structure of the system of equations [6]. This time-discontinuous Galerkin approach enables us to construct a family of algorithms for direct time integration [9]. The main feature of this family is that the algorithms have a hierarchical structure. This means that the system of equations of a particular order contains as a subset the equations of all methods of lower order or, in other words, the increased accuracy by this approach is obtained by adding one or more terms in the interpolation function, without modification of the previous ones. This is in contrast to traditional single-step integration methods, where increased accuracy may be obtained by reducing the time step length or by a change of integration methods, in this case a completely new system of equations has to be established and solved. However, the variational formulations of DG method lead to systems of coupled equations to be solved which are larger than those emanating from traditional semidiscrete approaches. The present paper introduces a new strategy for developing predictor-multicorrector algorithms which enables to reduce the computational effort. As far as the advantage is concerned, the hierarchical formulation is optimal because it allows for all information to be passed from one discretisation level to the second one and enables a convenient design of predictor-multicorrector algorithms which retain the stability in all phases of the numerical procedure.

We will consider a system of the ordinary differential equations associated with the semidiscrete form of linear elastodynamics

$$
[M] \ddot{\mathbf{u}}+[C] \mathbf{u}+[K] \mathbf{u}=\mathbf{F}(t), \quad t \in(0, T)
$$

with the initial conditions

$$
\mathbf{u}(0)=\mathbf{U}_{\mathbf{0}}, \quad \dot{\mathbf{u}}(0)=\dot{\mathbf{U}}_{\mathbf{0}}
$$

where $[M],[C]$ and $[K]$ are the mass, damping and 
stiffness matrices, respectively; $\mathbf{F}(t)$ is the prescribed vector of external load and $u$ is the vector of unknown nodal displacements. A superposed dot denotes differentiation with respect to time. $[M]$ is assumed to be symmetric positive-definite while $[C]$ and $[K]$ are assumed to be symmetric positive semi-definite.

\section{Time-discontinuous Galerkin algorithm}

The variational formulation of the considered timediscontinuous Galerkin method is:

Find $\mathbf{u} \in V$ such that $\forall \mathbf{v} \in V$,

$$
A(\mathbf{u}, \mathbf{v})_{n}=L(\mathbf{v})_{n}, \quad n=1,2 \ldots \ldots \ldots . . N
$$

where

$$
\begin{aligned}
& A(\mathbf{u}, \mathbf{v})_{n}=\left(\dot{\mathbf{v}} \mu_{n}, L \mathbf{u}\right)_{l_{n}}+\dot{\mathbf{v}}_{n-1}^{+}[M] \dot{\mathbf{u}}_{n-1}^{+}+ \\
& +\mathbf{v}_{n-1}^{+}[K] \mathbf{u}_{n-1}^{+} \\
& L(\mathbf{v})_{n}=\left(\dot{\mathbf{v}} \mu_{n}, \mathbf{F}\right)_{I_{n}}+\dot{\mathbf{v}}_{n-1}^{+}[M] \dot{\mathbf{u}}_{n-1}^{-}+ \\
& +\mathbf{v}_{n-1}^{+}[K] \mathbf{u}_{n-1}^{-} \\
& n=2, \ldots \ldots . . N \\
& L(\mathbf{v})_{1}=\left(\dot{\mathbf{v}} \mu_{n}, \mathbf{F}\right)_{I_{1}}+\dot{\mathbf{v}}_{0}^{+}[M] \dot{\mathbf{U}}_{0}+\mathbf{v}_{0}^{+}[K] \mathbf{U}_{0}(3.4)
\end{aligned}
$$

and

$$
L \mathbf{u}=[M] \ddot{\mathbf{u}}+[C] \dot{\mathbf{u}}+[K] \mathbf{u} .
$$

The details are given in [9]. Within a discrete time interval the unknown fields can be approximated by $k$-th order polynomials which are constructed from $k+1$ terms of a Taylor series expansion in time. For the sake of simplicity, the subsequent presentation is restricted to $k=2$. In this case the quadratic variation of displacement in the $n$-th time interval is assumed and can expressed be as follows

$$
\mathbf{u}^{h}(t)=\mathbf{u}_{n-1}^{+}+\left(t-t_{n-1}\right) \mathbf{v}_{n-1}^{+}+\frac{1}{2}\left(t-t_{n-1}\right)^{2} \mathbf{a}_{n}
$$

where the constant in time value $\mathbf{u}_{n-1}^{+}$defines the displacement at the beginning of the $n$-th time interval, $\mathbf{v}_{n-1}^{+}$defines the velocity at the beginning of the time interval, $\mathbf{a}_{n}$ is the constant acceleration. In this case, velocity varies linearly and is calculated using

$$
\mathbf{v}^{h_{1}}(t)=\mathbf{v}_{n-1}^{+}+\left(t-t_{n-1}\right) \mathbf{a}_{n}, t \in I_{n}
$$

Substituting eq (4) and (5) and their corresponding functions for the equation of the variational formu- lation of time-discontinuous Galerkin method (3) and performing integration explicitly we obtain a system of linear equations which can be expressed as

$$
\left[\begin{array}{ccc}
{[K]} & \mathbf{0} & \mathbf{0} \\
b_{1}[K] & {\left[A_{22}\right]} & {\left[A_{23}\right]} \\
b_{2}[K] & {\left[A_{32}\right]} & {\left[A_{33}\right]}
\end{array}\right]\left\{\begin{array}{c}
\mathbf{u}_{n-1}^{+} \\
\mathbf{v}_{n-1}^{+} \\
\mathbf{a}_{n}
\end{array}\right\}=\left\{\begin{array}{c}
{[K] \mathbf{u}_{n-1}^{-}} \\
{[M] \mathbf{v}_{n-1}^{-}+\mathbf{F}_{1 n}} \\
\mathbf{F}_{2 n}
\end{array}\right\}
$$

where $\mathbf{u}_{n-1}^{-}$and $\mathbf{v}_{n-1}^{-}$are the displacement and the velocity at the end of the previous $(n-1)$-th interval, respectively and submatrices can be expressed as

$$
\left[A_{22}\right]=[M]+b_{1}[C]+b_{2}[K]
$$

$$
\begin{gathered}
{\left[A_{23}\right]=b_{1}[M]+b_{2}[C]+\frac{1}{2} b_{3}[K]} \\
{\left[A_{32}\right]=b_{2}[C]+b_{3}[K]} \\
{\left[A_{33}\right]=b_{2}[M]+b_{3}[C]+\frac{1}{2} b_{4}[K]}
\end{gathered}
$$

The coefficients $b_{1}, b_{2}, b_{3}, b_{4}$ and $\mathbf{F}_{1 n}, \mathbf{F}_{2 n}$ are defined as follows

$$
b_{1}=\frac{1-e^{-\alpha \Delta t}}{\alpha}
$$

$$
\begin{gathered}
b_{2}=\frac{1-e^{-\alpha \Delta t}(\alpha \Delta t+1)}{\alpha^{2}} \\
b_{3}=\frac{2-e^{-\alpha \Delta t}\left(\alpha^{2} \Delta t^{2}+2 \alpha \Delta t+2\right)}{\alpha^{3}} \\
b_{4}=\frac{6-e^{-\alpha \Delta t}\left(\alpha^{3} \Delta t^{3}+3 \alpha^{2} \Delta t^{2}+6 \alpha \Delta t+6\right)}{\alpha^{4}} \\
\mathbf{F}_{1 / n}=\int_{I_{n-1}}^{t_{n}} \mu \mathbf{F} d t
\end{gathered}
$$$$
\mathbf{F}_{2 n}=\int_{t_{n-1}}^{t_{n}} \mu \mathbf{F}\left(t-t_{n-1}\right) d t
$$

where $\alpha>0$.

The direct solution of this equation system is computationally expensive. One approach in order to decrease the computational cost is to construct predictor-multicorrector algorithms. 


\section{Predictor-multicorrector algorithm}

In this section, we present the development of a new family of the predictor-multicorrector algorithms, based on time-discontinuous Galerkin method. The main idea of these algorithms is to cast the coupled equations in predictor-multicorrecror form. The goal is to reduce the computational effort while retaining the desirable accuracy and stability of the underlying fully coupled method.

Solving the system (6) in the predictormulticorrector form, the first equation of (6) defines the value of $\mathbf{u}_{n-1}^{+}$, i.e., $\mathbf{u}_{n-1}^{+}=\mathbf{u}_{n-1}^{-}$. The second and third equations of (6) are solved separately: for given an initial approximation (predictor value) of the acceleration, the second equation is solved for the velocity. Next, using the resultant velocity, the third equation is solved for the acceleration. Finally, using this updated acceleration, the second equation is again solved for the velocity. These two equations are solved repeatedly until desired accuracy is obtained. Proposed predictormulticorrector algorithm is cast as a residual-driven algorithm. This feature provides that the iterative solutions converge to the solution of the fully coupled method. The essence of the predictor-multicorrector algorithm, which is based on the time-discontinuous Galerkin approach using quadratic interpolation in time, is presented in following equations (Table). Note that the velocity equation is solved again after solving for the acceleration so that the updated acceleration properly influences the velocity. The maximum number of corrector passes affects the stability and the accuracy of the algorithm.

In the same way we can construct a whole family of predictor-multicorrector algorithms based on different interpolation functions of displacements.

\section{Stability and error analysis}

Since any $\mathrm{n}$ degrees of freedom coupled system can be decomposed into $\mathrm{n}$ uncoupled scalar equations, it can be established that the entire coupled system is reduced to consideration of the individual model equation [3].
Predictor-multicorrector algorithm based on quadratic interpolation function of displacements

A. Initialization

$$
\begin{aligned}
& \mathbf{u}\left(t_{0}^{-}\right)=\mathbf{u}_{0} \\
& \mathbf{v}\left(t_{0}^{-}\right)=\mathbf{v}_{0} \\
& t=0
\end{aligned}
$$

B. Time integration

a) Predictor phase

$$
\begin{array}{ll}
\mathbf{u}\left(t_{n-1}^{+}\right) & =\mathbf{u}\left(t_{n-1}^{-}\right) \\
\mathbf{v}\left(t_{n-1}^{+}\right)^{(0)} & =\mathbf{0} \\
\mathbf{a}_{n}^{(0)} & =\mathbf{0}
\end{array}
$$

b) Multicorrector phase

$$
\begin{aligned}
& {\left[M_{1}^{*},\right] \Delta \mathbf{v}^{(0)}=\mathbf{R}_{\mathrm{r}}^{(0)}} \\
& \mathbf{v}\left(t_{n-1}^{+}\right)^{(1)}=\mathbf{v}\left(t_{n-1}^{+}\right)^{(0)}+\Delta \mathbf{v}^{(0)}
\end{aligned}
$$

For $i=1, \ldots \ldots, i_{\text {max }}-1$

$$
\begin{aligned}
& {\left[M_{a}^{*}\right] \Delta \mathbf{a}^{(i-1)}=\mathbf{R}_{a}^{(i-1)}} \\
& \mathbf{a}_{n}^{(i)}=\mathbf{a}_{n}^{(i-1)}+\Delta \mathbf{a}^{(i-1)} \\
& {\left[M_{v}^{*}\right] \Delta \mathbf{v}^{(i)}=\mathbf{R}_{v}^{(i)}} \\
& \mathbf{v}\left(t_{n-1}^{+}\right)^{(i+1)}=\mathbf{v}\left(t_{n-1}^{+}\right)^{(i)}+\Delta \mathbf{v}^{(i)}
\end{aligned}
$$

Next $i$

$$
\begin{aligned}
\mathbf{u}\left(t_{n}^{-}\right)= & \mathbf{u}\left(t_{n-1}^{+}\right)+\Delta t \mathbf{v}\left(t_{n-1}^{+}\right)^{\left(i_{\max }\right)}+ \\
& +\frac{1}{2} \Delta t^{2} \mathbf{a}_{n}^{\left(i_{\max }-1\right)}
\end{aligned}
$$$$
\mathbf{v}\left(t_{n}^{-}\right)=\mathbf{v}\left(t_{n-1}^{+}\right)^{\left(i_{\max }\right)}+\Delta t \mathbf{a}_{n}^{\left(i_{\max }-1\right)}
$$$$
t=t+\Delta t
$$

If $t<T$, go to a), else terminate

Where

$$
\begin{aligned}
{\left[M_{1}^{*}\right]=} & {[M]+b_{1}[C]+b_{2}[K] } \\
\mathbf{R}_{v}^{(i)}= & {[M] \mathbf{v}\left(t_{n-1}^{-}\right)+\mathbf{F}_{1 n}-b_{1}[K] \mathbf{u}\left(t_{n-1}^{+}\right)-} \\
& -\left([M]+b_{1}[C]+b_{2}[K]\right) \mathbf{v}\left(t_{n-1}^{+}\right)^{(i)}- \\
& -\left(b_{1}[M]+b_{2}[C]+\frac{1}{2} b_{3}[K]\right) \mathbf{a}_{n}^{(i)} \\
\mathbf{R}_{a}^{(i)}= & \mathbf{F}_{2 n}-b_{2}[K] \mathbf{u}\left(t_{n-1}^{+}\right)-\left(b_{2}[C]+\right. \\
& \left.+b_{3}[K]\right) \mathbf{v}\left(t_{n-1}^{+}\right)^{(i)}-\left(b_{2}[M]+\right. \\
& \left.+b_{3}[C]+\frac{1}{2} b_{4}[K]\right) \mathbf{a}_{n}^{(i)}
\end{aligned}
$$


Thus the analysis is performed on the scalar single degree of freedom harmonic oscillator model problem with no damping or friction

$$
\ddot{d}+\left(\omega^{h}\right)^{2} d=0
$$

with

$$
d(0)=d_{0} \quad \text { and } \quad \dot{d}(0)=v_{0}
$$

where $\omega^{h}$ is the natural frequency of the system and $d$ is the displacement magnitude.

In the present analysis a particular emphasis is placed on the dissipative properties and the temporal accuracy of the proposed predictor-multicorrector algorithm.

For the purposes of analysis, it is useful to transform each of the numerical formulations to the discrete form, that is to express the values at the end of the time interval $\left(\mathbf{u}_{n}^{-}\right.$and $\left.\dot{\mathbf{u}}_{n}^{-}\right)$in terms of the values at the end of the previous time interval. This can be written in the form

$$
\left\{\begin{array}{c}
\mathbf{u}_{n}^{-} \\
\Delta t \dot{\mathbf{u}}_{n}^{-}
\end{array}\right\}=[A]\left\{\begin{array}{c}
\mathbf{u}_{n-1}^{-} \\
\Delta t \dot{\mathbf{u}}_{n-1}^{-}
\end{array}\right\}
$$

where $[A]$ is the numerical amplification matrix.

Convergence of a numerical formulation requires consistency and stability. Consistency can be determined from the truncation error. Stability is determined by spectral radius of the numerical amplification matrix which is defined by

$$
\rho([A])=\max _{i}\left|\lambda_{i}([A])\right|
$$

where $N$ is the dimension of the amplification matrix.

The formulation is unconditionally stable if the spectral radius is less than or equal to unity, ie

$$
\rho([A]) \leq 1 \text {. }
$$

Fig 1 depicts spectral radii of the implicit predictor-multicorrector scheme for two, three corrector passes and parent fully coupled algorithm. The fully coupled time-discontinuous Galerkin method using quadratic interpolation-in-time does not damp high frequency response $\left(\rho_{\infty}=1\right)$. However, the corresponding implicit predictor-multicorrector schemes exhibit numerical dissipation in the high frequency regime. The high frequency asymptotic limit of the spectral radius $\left(\rho_{\infty}\right)$ is 0.58 and 0.778 for two and three corrector passes, respectively.

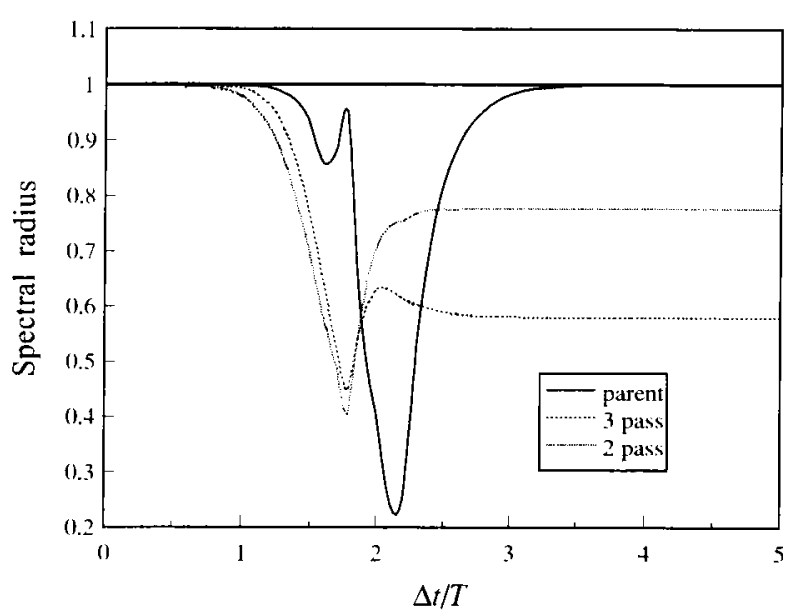

Fig 1. Spectral radii for the predictor-multicorrector algorithms based on quadratic-in-time interpolations for the time-discontinuous Galerkin method

When solving dynamical problems it is common procedure to separate the error in numerical schemes, into dissipation, namely, amplitude error, and dispersion, namely, phase error. Provided that the eigenvalues of $[A]$ remain complex $\left(\lambda_{1,2}([A])=A \pm i B, B \neq 0\right)$, algorithmic damping ratio provides a measure of the numerical dissipation and can be expressed

$$
\bar{\psi}^{h}=-\frac{\ln \rho}{\Delta t \omega}
$$

Algorithmic damping ratios are compared in Fig 2. The parent algorithm exhibits the least numerical dissipation followed by three-pass and the two-pass algorithms, in increasing order of algorithmic damping. The two-pass algorithm dissipation is still somewhat high in

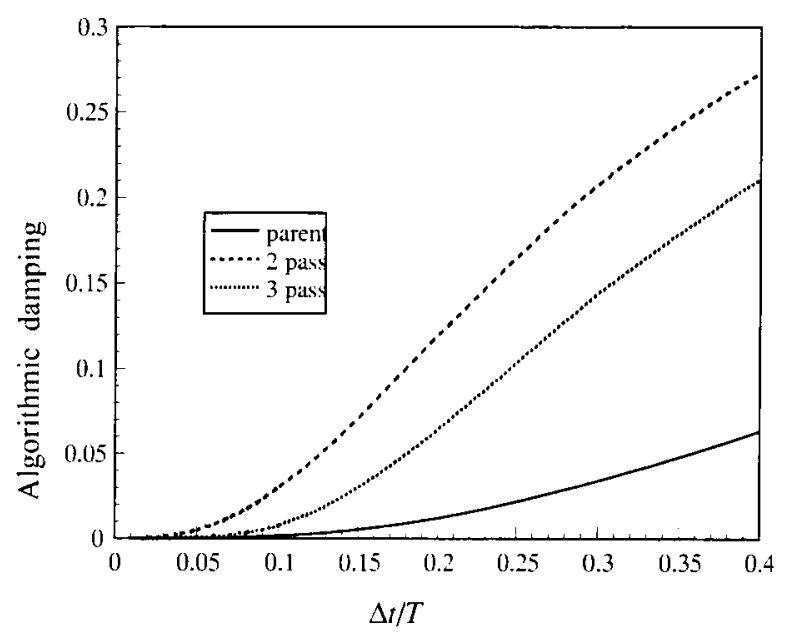

Fig 2. Algorithmic damping ratios for the predictormulticorrector algorithms based on quadratic-in-time interpolations for the time-discontinuous Galerkin method 
the low frequency regime to be of practical use. In contrast, the three-pass algorithm possesses good algorithmic damping characteristic in low frequency regime.

Dispersion in waves is generated when the phase velocity is a function of the frequency. The physical measure of the dispersion in one dimension (time) is the difference between analytical natural frequency and the numerical frequency.

The relative frequency error provides a measure of the numerical dispersion and in the numerical expression it is given by

$$
\frac{\omega^{h}}{\omega^{h}}-1, \text { where } \omega^{-h}=\Delta t^{-1} \tan ^{-1}\left(\frac{B}{A}\right) \text {. }
$$

Relative frequency errors in the low frequency domain are compared in Fig 3.

The third-order accuracy of the time finite element algorithms is clearly evident since the frequency error for these algorithms is substantially smaller than that of the Newmark algorithm

In order to establish the results of the global truncation error, a posteriori convergence rate in \|\|$_{1}$ norm is evaluated, where the error is defined by

$$
\|\boldsymbol{e}\|_{1}=\int_{0}^{T} a b s(\boldsymbol{U}-\boldsymbol{u}) d t
$$

where $U$ and $u$ are the exact and approximate solutions respectively.

The results of rate of convergence obtained using different numerical formulations are shown in Fig 4.

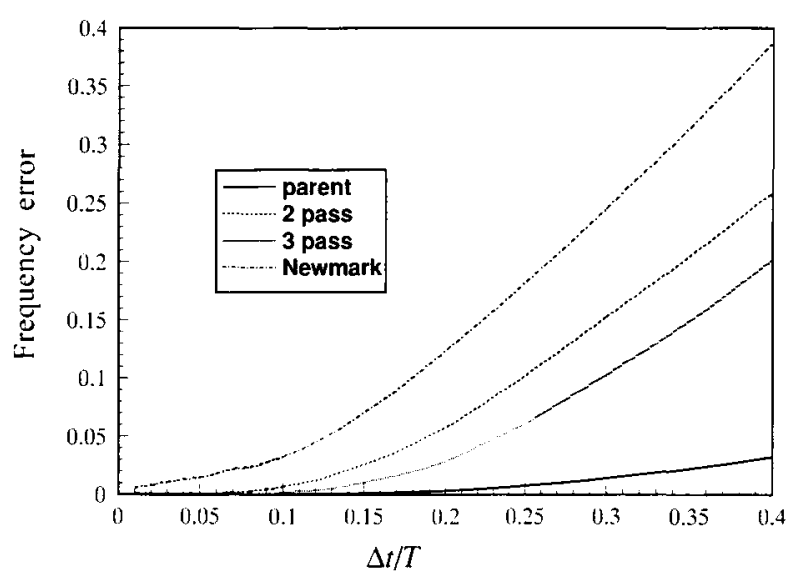

Fig 3. Relative frequency errors for the predictor-multicorrector algorithms based on quadratic-in-time interpolations for the time-discontinuous Galerkin method

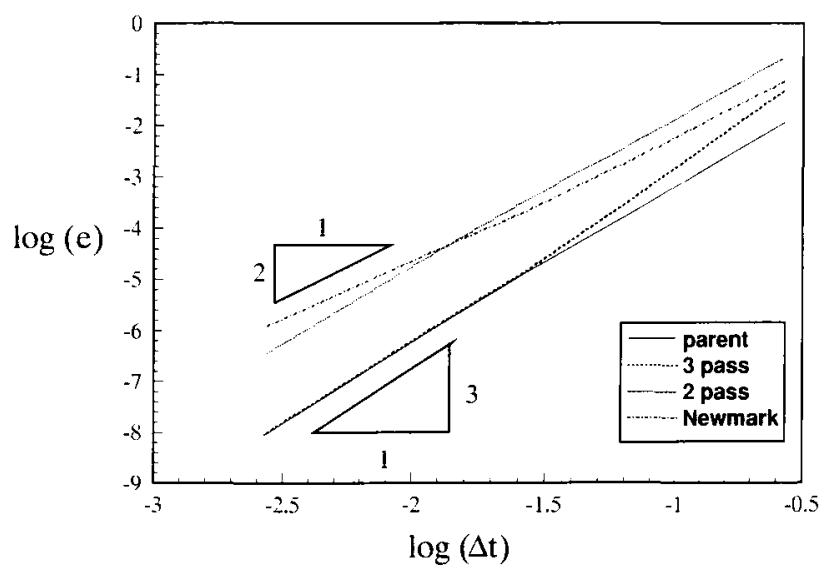

Fig 4. A posteriori rate of convergence by the predictor-multicorrector algorithms based on quadratic-in-time interpolations for the time-discontinuous Galerkin method

For the sake of comparison the convergence rates of parent algorithm and Newmark algorithm are also presented. The two-pass and three-pass algorithms demonstrate third-order accuracy. The three-pass algorithm agrees more closely with parent algorithm especially for smaller time steps.

\section{Conclusions}

The predictor-multicorrector algorithm for solution of second order ordinary differential equations associated with structural dynamics is presented. The proposed approach is based on new version of the timediscontinuous Galerkin method. The proposed algorithm is characterised by the stability condition, phase dissipation and frequency errors, a posteriori convergence rate.

\section{References}

1. M. A. Dokainish and K. Subbaraj. A Survey of Direct Time-Integration Methods in Computational Structural Dynamics-I. Explicit Methods // Comput. \& Struct., 32, 1989, p. $1371-1386$.

2. M. A. Dokainish and K. Subbaraj. A Survey of Direct Time-Integration Methods in Computational Structural Dynamics-II. Implicit Methods // Comput. \& Struct., 32, 1989, p. $1387-1401$.

3. T. J. R. Hughes. The Finite Element Method, Linear Static and Dynamic Finite Element Analysis. NJ: PrenticeHall, Englewood Cliffs, 1987. 789 p.

4. J. H. Argyris and D. W. Scharpf. Finite Elements in Time and Space // Nucl. Eng. Des., 10, 1969, p. 456464.

5. O. C. Zienkiewicz, W. L. Wood, N. W. Hine and R. L. Taylor. A Unified Set of Single Step Algorithms 
// Int. J. Numer. Methods Eng., 20, 1984, p. 1529-1552.

6. C. Johnson. Discontinuous Galerkin Finite Element Methods for Second Order Hyperbolic Problems // Methods Appl. Mech. Eng., 107, 1993, p. 117-129.

7. G. M. Hulbert. Time Finite Element Methods for Structural Dynamics // Int. J. Numer. Methods Eng., 33, 1992. p. $307-331$.

8. D. A. French. A Space-Time Finite Element Method for the Wave Equation // Comput. Methods Appl. Mech. Eng., 107, 1993, p. 145-157.

9. R. Baušys. Higher Order Integration Methods for Structural Dynamics Problems // Statyba, No 3(7), Vilnius: Technika, 1996, p. 6-12.

İteikta 20000908

\section{NAUJAS PROGNOZES IR MULTIKOREKCIJOS ALGORITMAS, SKIRTAS LAIKUI INTEGRUOTI STRUKTŨRINĖS DINAMIKOS UŽDAVINIUOSE}

\section{R. Baušys}

\section{Santrauka}

Trūkusis laike Galiorkino metodas leidžia sudaryti efektyvius struktūrinès dinamikos uždavinių sprendimo algoritmus. Šio metodo variacinè formuluoté pateikta lygtyje (3). Lygčiu sistema, gauta taikant kvadratines laiko interpoliacines funkcijas, yra pateikta lygtyje (6). Taikant originalu trūkuji laike Galiorkino metodą tenka spręsti didesnę lygčiu sistemą, palyginti su iprastiniais laiko integravimo algoritmais. Norint išvengti šio trūkumo, pasiūlytas naujas prognozès ir multikorekcijos algoritmas, skirtas laiko integravimui struktūrinés dinamikos uždaviniuose. Šio algoritmo sudarymo pagrindinè ideja yra atskiru pagrindiniu lygčiu liekamuju nariu minimizacija.
Šiuo atveju sprendžiamos tokio paties dydžio matricinès lygtys, kaip ir taikant iprastus laiko integravimo algoritmus. Tai leidžia sumažinti skaičiavimo sąnaudas kartu išlaikant tą pačią tikslumo klasę bei besąlygini stabiluma.

Pateiktas prognozès ir multikorekcijos algoritmas skirtas pagrindinei lygčiu sistemai (6) spręsti. Taikant prognozès ir multikorekcijos algoritma, pirmoji lygtis iš (6) sistemos apibrèžia $\mathbf{u}_{n-1}^{+}$reikšmę, t. y. $\mathbf{u}_{n-1}^{+}=\mathbf{u}_{n-1}^{-}$. Lygčiu sistemos (6) antroji ir trečioji lygtys sprendžiamos atskirai. Taikant pradinę pagreičio aproksimaciją (prognozès etapo reikšmę), sprendžiama antroji lygtis ir randamos greičiu reikšmès. Toliau, naudojant gautas greičiu reikšmes, sprendžiama trečioji lygtis ir apskaičiuojamos naujos pagreičiu reikšmès. Pabaigoje, irašius apskaičiuotas pagreičių reikšmes, vèl sprendžiama antroji lygtis ir nustatomos naujos patikslintos greičių reikšmès. Pakartotinai sprendžiant šias dvi lygtis, pasiekiamas norimas tikslumas. Kadangi taikant ši prognozès ir multikorekcijos algoritmą minimizuojami kiekvienos lygties liekamieji nariai, šio algoritmo sprendinys konverguoja prie visos lygčių sistemos sprendinio. Prognozès ir multikorekcijos algoritmo pagrindinès lygtys pateiktos lentelèje.

Pagrindinès algoritmo charakteristikos nustatomos klasikiniais modalinès analizès būdais. Gautos charakteristikos palyginamos su kitais metodais.

Romualdas BAUŠYS. Doctor Habil, Associate Professor. Vilnius Gediminas Technical University (VGTU), Dept of Engineering Mechanics. Saulètekio al. 11, LT-2040 Vilnius, Lithuania. E-mail: romas $@$ fm.vtu.lt

Doctor (1989), Doctor Habil (2000). Common research work with scientists from Chalmers University of Technology (Göteborg. Sweden). Research interests: problems of error estimation and adaptive finite element strategies in statics and dynamics. 